\title{
ASSESSMENT OF CARBON STOCK OF TREE VEGETATION IN THE KOLLI HILL FOREST LOCATED IN INDIA
}

\author{
ARUL PRAGASAN, L. \\ Department of Environmental Sciences, \\ Bharathiar University, Coimbatore - 641046, India \\ e-mail: arulpragasan@yahoo.co.in \\ (phone: +91-422-2428392) \\ (Received $9^{\text {th }}$ May 2015; accepted $11^{\text {th }}$ Feb 2016)
}

\begin{abstract}
Forest ecosystems covering approximately $30 \%$ of the terrestrial area of the earth play a significant role in the atmospheric carbon cycle that influence global warming and climate change. Assessment of carbon stock in forest vegetation is necessary for atmospheric carbon mitigation plans. The present study aimed to assess the total carbon stock in tree vegetation of Kolli hill (KH), a reserve forest located in India. The land area of KH $\left(508 \mathrm{~km}^{2}\right)$ was parted by $6.25 \times 6.25 \mathrm{~km}^{2}$ grids. In each grid, a transect of $0.5 \mathrm{ha}(5 \mathrm{~m} \times 1000 \mathrm{~m})$ was laid randomly, and all live trees greater than or equal to $30 \mathrm{~cm}$ girth $(=9.55 \mathrm{~cm}$ diameter $)$ measure at breast height were sampled. Carbon stock of each tree was determined by non-destructive method. The carbon stock estimated for $\mathrm{KH}$ forest was $73.7 \pm 13.6 \mathrm{tC} / \mathrm{ha}$. Maximum carbon stock was shared by Alseodaphne semicarpifolia var. semecarpifolia $(14 \%)$ among 157 species and Lauraceae (19\%) among 49 families recorded at KH. Statistical analysis revealed that the carbon stock values varied significantly among the eleven tree size classes $\left(\right.$ ANOVA, $\left.F_{(10,187)}=4.439, p<0.001\right)$ and among the three major forest types $\left(F_{(2,15)}=6.101, p<0.05\right)$ recognized. Regression analysis was also performed to test the relationship of carbon stock with tree density, species richness and altitude. The present study provides valuable data useful for better management and monitoring of $\mathrm{KH}$ forest with regard to tree carbon storage in mitigation of global warming and climate change.
\end{abstract}

Keywords: carbon stock; Kolli hill; India; tropical forest; tree vegetation

\section{Introduction}

Carbon dioxide, one of the greenhouse gases, has been increasing in concentration due to anthropogenic activities worldwide, and elevates the earth's average temperature by greenhouse effect. Increase in temperature causes global warming and climate change. It has been predicted that the mean global temperature will increase by $1.1^{\circ} \mathrm{C}$ to $6.4^{\circ} \mathrm{C}$ by the year 2100 (IPCC, 2007). Atmospheric carbon concentration was around $270 \mathrm{ppm}$ at the beginning of industrial revolution, it has crossed $400 \mathrm{ppm}$ by 2015 (NOAA, 2015), and scientists have predicted by 2070 carbon level will reach up to 500 ppm (Jackson et al., 2014). Climate change due to increase in carbon emissions leads to great challenges for carbon mitigation strategies, besides socio-economic, biological problems (Sicard \& Dalstein-Richer, 2015) and origin of new catastrophic diseases (WHO, 2015). In recent years, all possible steps have been taken by the developed nations in order to plan for carbon mitigation, management and policy actions. Most industrialized counties have signed the Kyoto Protocol to reduce their carbon outputs, carbon tax and subsidy systems have been developed in support of carbon mitigation targets (Cao et al., 2010).

Forest ecosystems cover approximately $30 \%$ of the terrestrial area of the world (Muraoka et al., 2015), and they are greatly recognized as important elements of global carbon as well as various other greenhouse gases that are believed to considerably affect climate (Teobaldelli et al., 2009). Trees exchange carbon dioxide with the atmosphere through biological processes and act as a major carbon sink by stocking carbon as fixed 
biomass, hence, assessment of tree carbon stock in forest systems is necessary to understand the potential of forests as carbon sinks.

Carbon stock of a tree is determined by its biomass. Tree biomass can be quantified using both destructive and non-destructive sampling methods. Destructive sampling method involves felling of trees is mostly adopted for plantation forests. Nondestructive sampling method, widely used for natural forests, involves estimation of biomass from forest inventory data by using either biomass equations (BE) or biomass expansion factors (BEF), conversion factors (wood density) or biomass conversion and expansion factors $(\mathrm{BCEF})$. $\mathrm{BE}$ requires tree level data like diameter at breast height or additionally height, age, etc., BEF needs volume data from forest inventory and BCEF is a combination of the first two factors (Teobaldelli et al., 2009).

Although, many studies have been done to quantify the forest carbon stocks worldwide, there are still some forest systems which remain unexplored in India. The present study was undertaken in Kolli hill $(\mathrm{KH})$ forest with the main objective to assess the carbon stock (tC/ha) of tree vegetation in the forest system. This paper also presents the analysis on carbon stocks by different tree species, families, forest types, and stem size classes. Further, an attempt was also made to discuss the relationship of tree carbon stock with species richness, density and altitude.

\section{Materials and methods}

The present study site $\mathrm{KH}$ is located in India, between latitudes $11^{\circ} 11.0^{\prime}-11^{\circ} 28.0^{\prime} \mathrm{N}$ and longitudes $78^{\circ} 17.0-78^{\circ} 29.0^{\prime} \mathrm{E}$ (Fig. 1). The study site covering about $508 \mathrm{~km}^{2}$ of land area falls under national reserve forest category consists of varied metamorphic rocks, and red lateritic soil. The site comes under tropical climate zone with four seasons: summer (late February to June), pre-monsoon (July to August), monsoon (September to November), post monsoon (December to mid February). The mean annual temperature for the past 20 years (data obtained from the regional meteorological center) is $28.3^{\circ} \mathrm{C}$, and the rainfall is $1058 \mathrm{~mm}$ per year.

The complete study site was parted by $6.25 \mathrm{~km} \times 6.25 \mathrm{~km}$ grids, and that summed up to 18 grids. In each grid, a transect of 0.5 ha $(5 \mathrm{~m} \times 1000 \mathrm{~m})$ was laid randomly, to facilitate sampling each transect was subdivided into fifty $5 \mathrm{~m} \times 20 \mathrm{~m}(10$ sq. $\mathrm{m})$ quadrats, and all live trees greater than or equal to $30 \mathrm{~cm}$ girth $(9.55 \mathrm{~cm}$ diameter) measure at breast height $(1.37 \mathrm{~m}$ from the ground level) were sampled (Pragasan \& Parthasarathy, 2010). Stem girth measure of each tree was noted using measuring tape. A sum of 3824 trees representing 157 species in 49 families was recorded from the 18 transects (900 quadrats) sampled. Tree density, species richness was calculated, and altitude was noted for each transect. Density was determined as the number of individuals per unit area: $D i=n i / A$, where $D i$ is the density of species $i, n i$ is the total number of individuals recorded for species $i$, and $A$ is the total area sampled. Density for each transect was calculated as the sum of the densities of all the species $\left(\sum D\right)$, and expressed as individuals/ha. Species richness was determined as the numbers of different tree species recorded per transect and expressed as species/transect. Altitude was noted using global positioning system (GPS Garmin) and expressed as $\mathrm{m}$ asl.

Carbon stock of each tree was calculated as $50 \%$ of its biomass following Timilsina et al., 2014 and others (Atjay et al., 1979; Brown \& Lugo, 1982; Dixon et al., 1994; Takimoto et al., 2008; Bhat \& Ravindranath, 2011; Mohanraj et al., 2011). Tree biomass was calculated as sum of its aboveground biomass and below ground biomass. 
Aboveground biomass was calculated using BE method formulated by Brown et al. (1989), adopted for tropical species: $Y=\mathrm{a}-\mathrm{b} X+\mathrm{c} X^{2}$, where $Y$ is aboveground biomass in $\mathrm{kg}, X$ is stem diameter at breast height in $\mathrm{cm}$, and $\mathrm{a}, \mathrm{b}$ and $\mathrm{c}$ are constant values $34.4703,8.0671$ and 0.6589 , respectively. Stem diameter of each tree was calculated from its girth measure at breast height: $d=C / \pi$, where $d$ is stem diameter in $\mathrm{cm}, C$ is stem girth measure at breast height in $\mathrm{cm}$, and $\pi$ is an universal constant value 3.14. Below ground biomass was considered as $15 \%$ of the aboveground biomass as adopted by Miria \& Khan, 2015 and others (MacDicken, 1997; Alamgir \& Al-Amin, 2008).

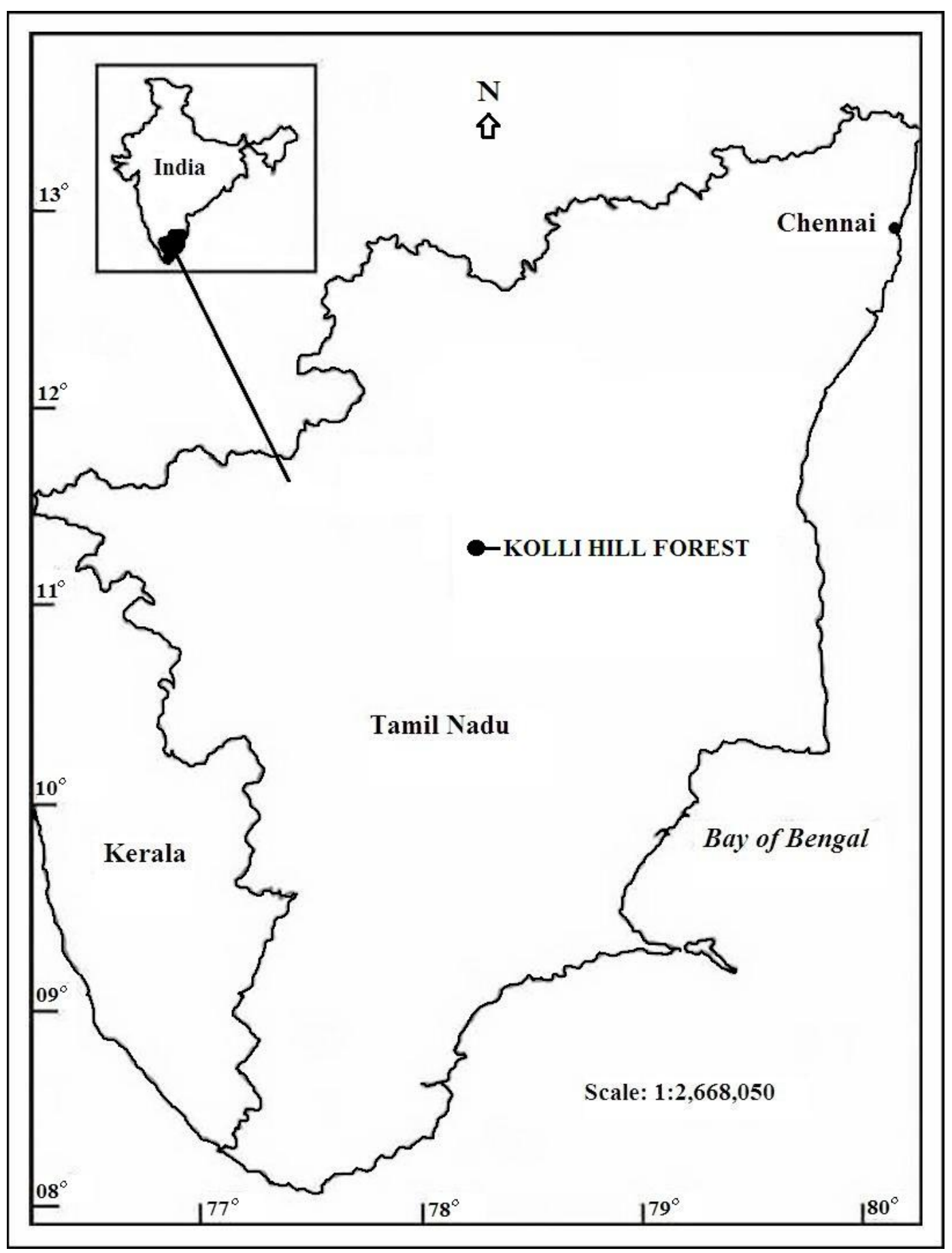

Figure 1. Map showing the location of the study area, Kolli hill forest in India 
Transects $(\mathrm{n}=18)$ sampled from the study site were categorized into, three forest types semi-evergreen $(n=11)$, mixed deciduous $(n=3)$ and scrub $(n=4)$ forests (based on vegetation characters), three altitudinal ranges low altitude (less than $500 \mathrm{~m}$ asl, $\mathrm{n}=5$ ), medium altitude (500-1000 $\mathrm{m}$ asl, $\mathrm{n}=7$ ) and high altitude (above $1000 \mathrm{~m}$ asl, $\mathrm{n}=6$ ). Trees $(n=3824)$ sampled from the 18 transects were categorized (based on stem girth measure) into eleven stem size classes $30-60 \mathrm{~cm}$ class, $60-90 \mathrm{~cm}, 90-120 \mathrm{~cm}, 120-150 \mathrm{~cm}, 150-$ $180 \mathrm{~cm}, 210-240 \mathrm{~cm}, 240-270 \mathrm{~cm}, 270-300 \mathrm{~cm}, 300-330 \mathrm{~cm}$ and greater than $330 \mathrm{~cm}$.

Tree carbon stock (tC/ha) for each forest type, altitudinal range, stem size class was determined, and analysis of variance (ANOVA) was used to test the significance of variation in carbon stock among forest types, altitudinal ranges and stem tree size classes. Regression analysis was performed to test the relationship of carbon stock (tC/ha) with tree density (individuals/ha), species richness (species/transect) and altitude ( $\mathrm{m}$ asl).

\section{Results}

\section{Tree density and species richness}

Tree density was recorded as low as 278 individuals/ha for Transect17 to a high of 632 individuals/ha for Transect4 (Table 1), and the mean value for the 18 transects was $425 \pm 25$ individuals/ha ( \pm S.E.). Species richness was recorded minimum (10 species/transect) for Transect17 and maximum (42 species/transect) for Transect2 (Table 1), and the mean value for the 18 transects was $27 \pm 2$ species/transect.

Table 1. Tree carbon stock estimated for the eighteen 0.5ha transects sampled from the Kolli hill forest located in India. SE-semi-evergreen; MD-mixed deciduous; SB-scrub

\begin{tabular}{cccccc}
\hline Transect & $\begin{array}{c}\text { Forest } \\
\text { type }\end{array}$ & $\begin{array}{c}\text { Altitude } \\
\text { (m asl) }\end{array}$ & $\begin{array}{c}\text { Density } \\
\text { (individuals/ha) }\end{array}$ & $\begin{array}{c}\text { Species richness } \\
\text { (species/transect) }\end{array}$ & $\begin{array}{c}\text { Carbon } \\
\text { stock } \\
\text { (tC/ha) }\end{array}$ \\
\hline Transect1 & SE & 1128 & 590 & 33 & 141.7 \\
Transect2 & SE & 973 & 586 & 42 & 204.5 \\
Transect3 & SE & 1127 & 414 & 24 & 125.6 \\
Transect4 & SE & 797 & 632 & 38 & 104.9 \\
Transect5 & SE & 1301 & 522 & 31 & 173.6 \\
Transect6 & SE & 912 & 294 & 42 & 70.7 \\
Transect7 & SE & 1274 & 330 & 29 & 48.8 \\
Transect8 & MD & 587 & 452 & 36 & 26.6 \\
Transect9 & SE & 1100 & 370 & 17 & 72.5 \\
Transect10 & SE & 1132 & 490 & 18 & 66.6 \\
Transect11 & SE & 994 & 374 & 29 & 108.6 \\
Transect12 & SE & 427 & 474 & 14 & 21.2 \\
Transect13 & SB & 514 & 466 & 27 & 23.0 \\
Transect14 & MD & 353 & 384 & 30 & 48.9 \\
Transect15 & SB & 305 & 352 & 23 & 41.2 \\
Transect16 & SB & 577 & 326 & 17 & 11.6 \\
Transect17 & SB & 384 & 278 & 10 & 10.0 \\
Transect18 & MD & 337 & 314 & 27 & 27.1 \\
\hline
\end{tabular}




\section{Carbon stock}

Tree carbon stock was recorded minimum $10.0 \mathrm{tC} / \mathrm{ha}$ for Tansect17 and maximum carbon value $204.5 \mathrm{tC} / \mathrm{ha}$ was observed for Transect2 (Table 1), and the mean carbon value for the 18 transects sampled was $73.7 \pm 13.6 \mathrm{tC} / \mathrm{ha}$.

\section{Forest type}

Among the three forest types recognized, carbon stock of semi-evergreen forest $(103.5 \pm 16.6 \mathrm{tC} / \mathrm{ha})$ was found three folds greater than the mixed-deciduous and almost five folds greater than scrub forests (Fig. 2). The carbon stock (tC/ha) value among the forest types varied significantly (ANOVA: $F_{(2,15)}=6.101, p<0.05$ ).

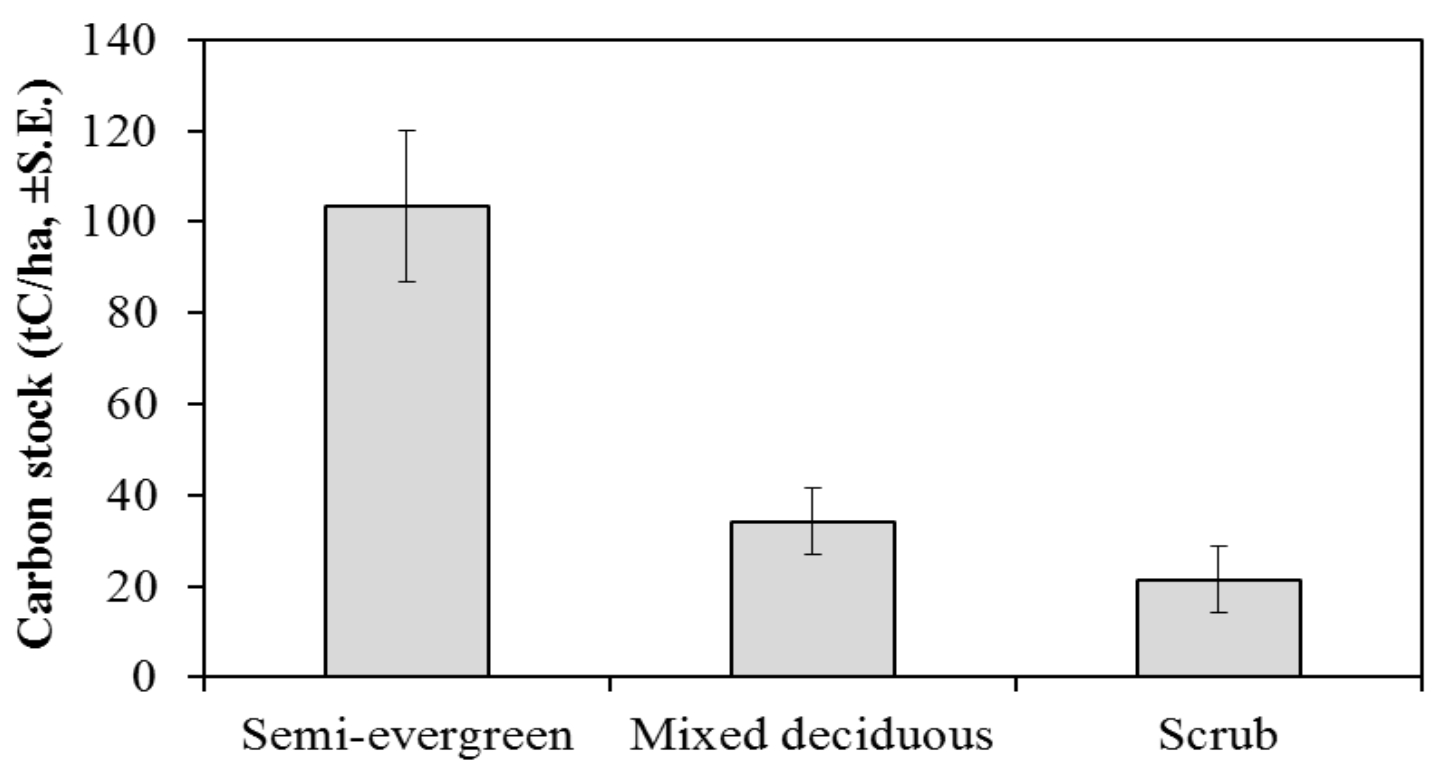

Figure 2. Comparison of carbon stock between the three major forest types

\section{Altitudinal gradient}

Among the three altitudinal ranges classified, carbon stock was recorded maximum for high altitude range $(104.8 \pm 20.1 \mathrm{tC} / \mathrm{ha})$ followed by medium $(78.6 \pm 25.7 \mathrm{tC} / \mathrm{ha})$ and low altitude range $(29.7 \pm 7.0 \mathrm{tC} / \mathrm{ha})$. The carbon stock $(\mathrm{tC} / \mathrm{ha})$ value among the three altitudinal ranges did not vary significantly (ANOVA: $\left.F_{(2,15)}=2.871, p>0.05\right)$.

\section{Stem size class}

Of the total eleven stem size classes recognized, $120-150 \mathrm{~cm}$ class recorded maximum carbon value $(5.9 \pm 1.2 \mathrm{tC} / \mathrm{ha})$, followed by $90-120 \mathrm{~cm}$ class, $60-90 \mathrm{~cm}, 180-$ $210 \mathrm{~cm}$ and $210-240 \mathrm{~cm}$ class (Fig. 3). ANOVA revealed a significant variation in carbon stock value among the 11 stem size classes $\left(F_{(10,187)}=4.439, p<0.0001\right)$. 


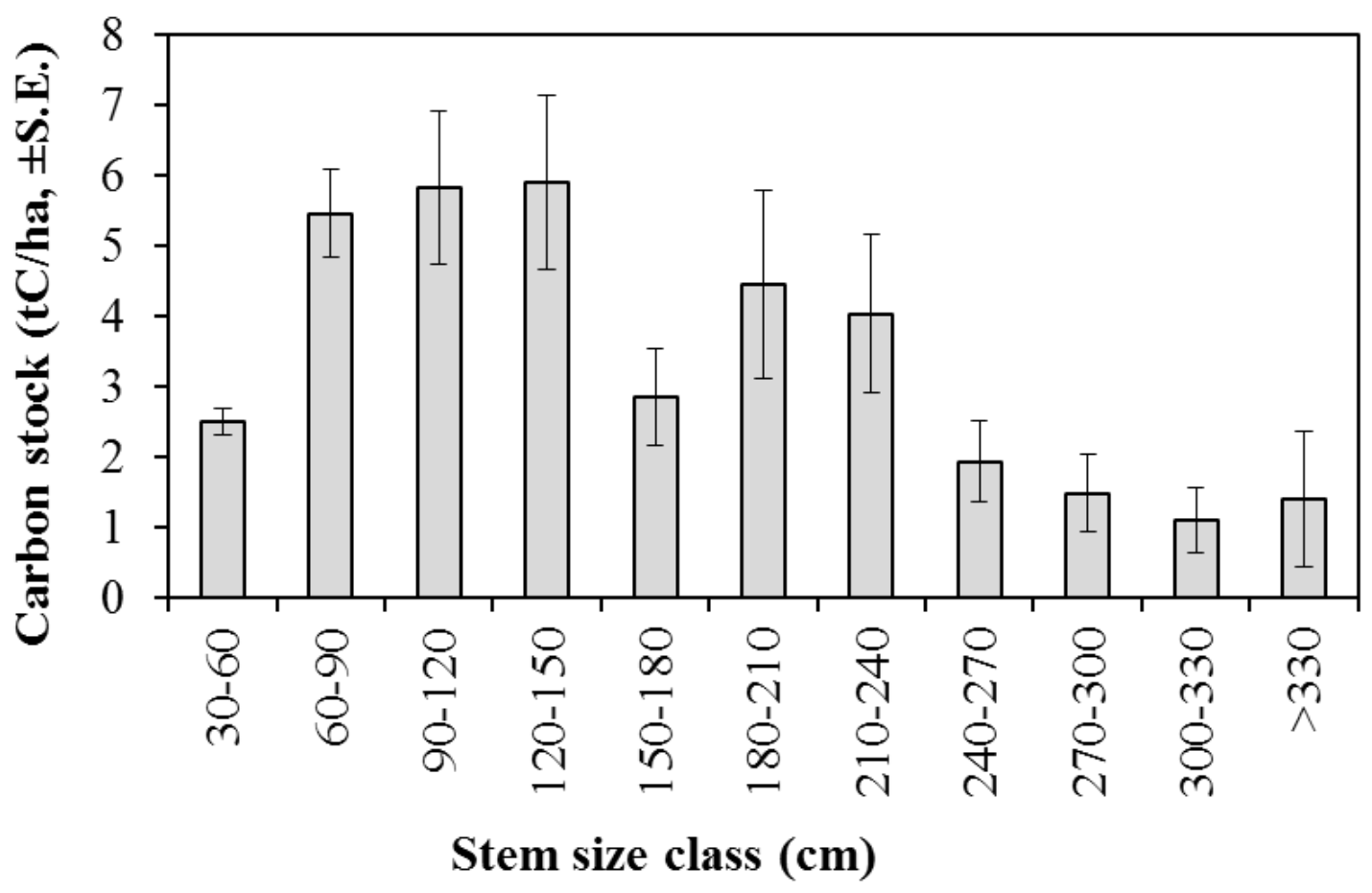

Figure 3. Distribution of carbon stock among the eleven stem size classes

\section{Species}

Out of the 157 species recorded, the total carbon stock was found maximum (92.34 tC/9ha, $14 \%$ ) for Alseodaphne semicarpifolia var. semecarpifolia followed by Syzygium cumini, Memecylon edule, Canarium strictum and Mangifera indica (Table 2 ). The average carbon stock (tC/tree) was recorded maximum for Sterculia foetida (1.89 tC/tree) followed by Ficus amplissima, Ficus beddomei, Mitragyna parvifolia and Ficus benghalensis (Table 2).

Table 2. Carbon stock of tree species recorded from the Kolli hill forest, India

\begin{tabular}{lccc}
\hline Species (Family) & $\begin{array}{c}\text { Number of } \\
\text { individuals } \\
\text { (for 9 ha) }\end{array}$ & $\begin{array}{c}\text { Total } \\
\text { carbon } \\
\text { stock } \\
\text { (tC/9ha) }\end{array}$ & $\begin{array}{c}\text { Average } \\
\text { carbon } \\
\text { stock } \\
\text { (tC/tree) }\end{array}$ \\
\hline $\begin{array}{l}\text { Alseodaphne semicarpifolia Nees var. } \\
\text { semecarpifolia } \text { (Lauraceae) }\end{array}$ & 128 & 92.34 & 0.72 \\
Syzygium cumini (L.) Skeels (Myrtaceae) & 137 & 69.36 & 0.51 \\
Memecylon edule Roxb. (Melastomataceae) & 654 & 44.41 & 0.07 \\
Canarium strictum Roxb. (Burseraceae) & 37 & 34.08 & 0.92 \\
Mangifera indica L. (Anacardiaceae) & 27 & 24.27 & 0.90 \\
Neolitsea scrobiculata (Meisner) Gamble & 134 & 22.90 & 0.17 \\
(Lauraceae) & & & \\
Prunus ceylanica (Wight) Miq. (Rosaceae) & 34 & 22.78 & 0.67 \\
Artocarpus heterophyllus Lam. (Moraceae) & 24 & 16.91 & 0.70 \\
Ficus amplissima J.E. Smith (Moraceae) & 9 & 14.69 & 1.63 \\
Ficus microcarpa L.f. (Moraceae) & 13 & 14.11 & 1.09
\end{tabular}


Tamarindus indica L. (Caesalpiniaceae)

Anogeissus latifolia (Roxb. ex DC.) Wall. ex

Guill. \& Perr. (Combretaceae)

Myristica dactyloides Gaertn. (Myristicaceae)

Elaeocarpus serratus L. (Elaeocarpaceae)

Commiphora caudata (Wight \& Arn.) Engler

(Burseraceae)

Moringa concanensis Nimmo ex Gibs.

(Moringaceae)

Ficus beddomei King (Moraceae)

Vitex altissima L.f. (Verbenaceae)

$10.33 \quad 0.20$

Euphorbia antiquorum L. (Euphorbiaceae)

$9.80 \quad 0.03$

Mitragyna parvifolia (Roxb.) Korth. (Rubiaceae)

9.79

1.40

Diospyros ebenum Koen. (Ebenaceae)

9.42

0.24

Bischofia javanica Blume (Bischofiaceae)

9.35

0.45

Ficus mollis Vahl (Moraceae)

8.75

Scolopia crenata (Wight \& Arn.) Clos

8.09

0.22

(Flacourtiaceae)

Gyrocarpus asiaticus Willd. (Hernandiaceae)

Celtis philippensis Blanco (Ulmaceae)

7.59

0.11

Nothopegia heyneana (Hook.f.) Gamble

(Anacardiaceae)

Albizia amara (Roxb.) Boivin (Mimosaceae)

6.43

0.12

Ficus benghalensis L. (Moraceae)

Pterocarpus marsupium Roxb. (Papilionaceae)

Terminalia bellirica (Gaertn.) Roxb.

(Combretaceae)

Memecylon grande Retz. (Melastomataceae)

Premna tomentosa Roxb. (Verbenaceae)

Chloroxylon swietenia DC. (Flindersiaceae)

Litsea deccanensis Gamble (Lauraceae)

Canthium dicoccum (Gaertn.) Teijsm. \& Binn. var. umbellata (Wight) Sant. \& Merch.

(Rubiaceae)

Sterculia foetida L. (Sterculiaceae)

Symplocos cochinchinensis (Lour.) Moore

4.46

0.18

(Symplocaceae)

Chrysophyllum roxburghii G.Don (Sapotaceae)

Diospyros barberi Ramaswami (Ebenaceae)

Pleiospermium alatum (Wall. ex Wight \& Arn.)

Swingle (Rutaceae)

Pterospermum xylocarpum (Gaertn.) Sant. \&

Wagh (Sterculiaceae)

Filicium decipiens (Wight \& Arn.) Thw.

(Sapindaceae)

Ficus drupacea Thunb. var. pubescens (Roth)

Corner (Moraceae)

Commiphora berryi (Arn.) Engler (Burseraceae) 
Drypetes sepiaria (Wight \& Arn.) Pax \& Hoffm.

49

$2.45 \quad 0.05$

(Euphorbiaceae)

Cassine glauca (Rottb.) Kuntze (Celastraceae)

$\begin{array}{lll}16 & 2.26 & 0.14\end{array}$

Wrightia tinctoria (Roxb.) R.Br. (Apocynaceae)

$29 \quad 2.23$

0.08

Drypetes roxburghii (Wall.) Hurusawa

15

2.21

0.15

(Euphorbiaceae)

Phoebe lanceolata Nees (Lauraceae)

9

2.20

0.24

Remaining 107 species

885

51.40

0.13

\section{Family}

Among the 49 families recorded, total tree carbon stock was found maximum (126.10 tC/9ha, $19 \%)$ for Lauraceae followed by Moraceae, Myrtaceae, Melastomataceae and Burseraceae (Table 3).

Table 3. Carbon stock of 49 families recorded from the Kolli hill forest, India

\begin{tabular}{|c|c|c|c|c|}
\hline Family & $\begin{array}{l}\text { Number of } \\
\text { species } \\
\text { (for } 9 \text { ha) }\end{array}$ & $\begin{array}{c}\text { Number of } \\
\text { individuals } \\
\text { (for } 9 \text { ha) }\end{array}$ & $\begin{array}{c}\text { Total } \\
\text { carbon stock } \\
\text { (tC/9ha) }\end{array}$ & $\begin{array}{l}\text { Average } \\
\text { carbon stock } \\
\text { (tC/tree) }\end{array}$ \\
\hline Lauraceae & 11 & 307 & 126.10 & 0.41 \\
\hline Moraceae & 14 & 111 & 77.35 & 0.70 \\
\hline Myrtaceae & 3 & 140 & 69.41 & 0.50 \\
\hline Melastomataceae & 3 & 709 & 49.47 & 0.07 \\
\hline Burseraceae & 3 & 185 & 48.36 & 0.26 \\
\hline Anacardiaceae & 6 & 92 & 32.33 & 0.35 \\
\hline Rosaceae & 1 & 34 & 22.78 & 0.67 \\
\hline Euphorbiaceae & 14 & 498 & 20.39 & 0.04 \\
\hline Combretaceae & 3 & 40 & 17.94 & 0.45 \\
\hline Verbenaceae & 5 & 91 & 16.56 & 0.18 \\
\hline Rubiaceae & 11 & 113 & 16.06 & 0.14 \\
\hline Ebenaceae & 6 & 132 & 15.82 & 0.12 \\
\hline Caesalpiniaceae & 2 & 25 & 13.53 & 0.54 \\
\hline Myristicaceae & 1 & 31 & 12.25 & 0.40 \\
\hline Elaeocarpaceae & 1 & 44 & 11.76 & 0.27 \\
\hline Moringaceae & 1 & 50 & 11.45 & 0.23 \\
\hline Mimosaceae & 5 & 256 & 9.46 & 0.04 \\
\hline Bischofiaceae & 1 & 21 & 9.35 & 0.45 \\
\hline Papilionaceae & 4 & 39 & 8.88 & 0.23 \\
\hline Flacourtiaceae & 3 & 39 & 8.20 & 0.21 \\
\hline Sterculiaceae & 3 & 29 & 7.89 & 0.27 \\
\hline Hernandiaceae & 1 & 72 & 7.59 & 0.11 \\
\hline Ulmaceae & 3 & 97 & 7.17 & 0.07 \\
\hline Sapindaceae & 5 & 59 & 6.33 & 0.11 \\
\hline Meliaceae & 7 & 51 & 5.47 & 0.11 \\
\hline Rutaceae & 7 & 285 & 5.11 & 0.02 \\
\hline Flindersiaceae & 1 & 54 & 4.50 & 0.08 \\
\hline Apocynaceae & 2 & 35 & 3.81 & 0.11 \\
\hline
\end{tabular}




\begin{tabular}{lcccc} 
Symplocaceae & 1 & 21 & 3.54 & 0.17 \\
Sapotaceae & 2 & 6 & 3.49 & 0.58 \\
Celastraceae & 1 & 16 & 2.26 & 0.14 \\
Annonaceae & 2 & 26 & 1.49 & 0.06 \\
Loganiaceae & 2 & 38 & 1.42 & 0.04 \\
Oleaceae & 2 & 22 & 1.28 & 0.06 \\
Bignoniaceae & 2 & 5 & 1.22 & 0.24 \\
Meliosmaceae & 2 & 3 & 0.91 & 0.30 \\
Asteraceae & 1 & 7 & 0.84 & 0.12 \\
Bombacaceae & 1 & 1 & 0.72 & 0.72 \\
Cordiaceae & 3 & 18 & 0.53 & 0.03 \\
Myrsinaceae & 1 & 5 & 0.14 & 0.03 \\
Tiliaceae & 1 & 2 & 0.10 & 0.05 \\
Erythroxylaceae & 1 & 1 & 0.07 & 0.02 \\
Araliaceae & 1 & 4 & 0.06 & 0.06 \\
Alangiaceae & 1 & 2 & 0.05 & 0.01 \\
Rhamnaceae & 2 & 1 & 0.03 & 0.02 \\
Proteaceae & 1 & 1 & 0.02 & 0.02 \\
Arecaceae & 1 & 1 & 0.01 & 0.01 \\
Lecythidaceae & 1 & 1 & 0.01 & 0.01 \\
Solanaceae & 1 & 0.01 & 0.01 \\
\hline
\end{tabular}

\section{Regression analysis}

Regression analysis revealed that there exist no relationship between carbon stock with tree species richness $\left(r^{2}=0.301\right)$, density $\left(r^{2}=0.398\right)$ and altitude $\left(r^{2}=0.469\right)$ of for the 18 transects analyzed (Fig. 4).

\section{Discussion}

Currently, international concern on the treat of increased concentration of greenhouse gases particularly atmospheric carbon concentration on global warming and climate change made the super power nations to convene meetings for serious discussions, on reduction of carbon emissions, carbon mitigation policies such as on carbon tax and subsidy. Clean Development Mechanism (CDM) forestry projects began from 2006 in light of carbon offsetting targets, then, the Climate Action Reserve (CAR) projects, Verified Carbon Standard (VCS) and the American Carbon Registry (ACR) came into action (Pearson et al., 2014). Although, several policies and carbon market business were taken, the rise in atmospheric carbon concentration and its consequence are at alarming rate. Carbon storage in terrestrial vegetation is one of the promising natural phenomena in regard to carbon mitigation strategy. Carbon sequestration in vegetation mostly occurs either by expansion of forests or by conserving them (Houghton, 1996), hence, forest expansions and sustainable forest management have a significant role in the protection of environment (Shah et al., 2014). On the other hand, shrinkage of forests may have a strong negative role in achieving carbon targets, and a long term influence and impact (Levy et al., 2004). So, understanding the dynamics of carbon stocks and carbon changes are a key for sustainable management of forest carbon sinks. 

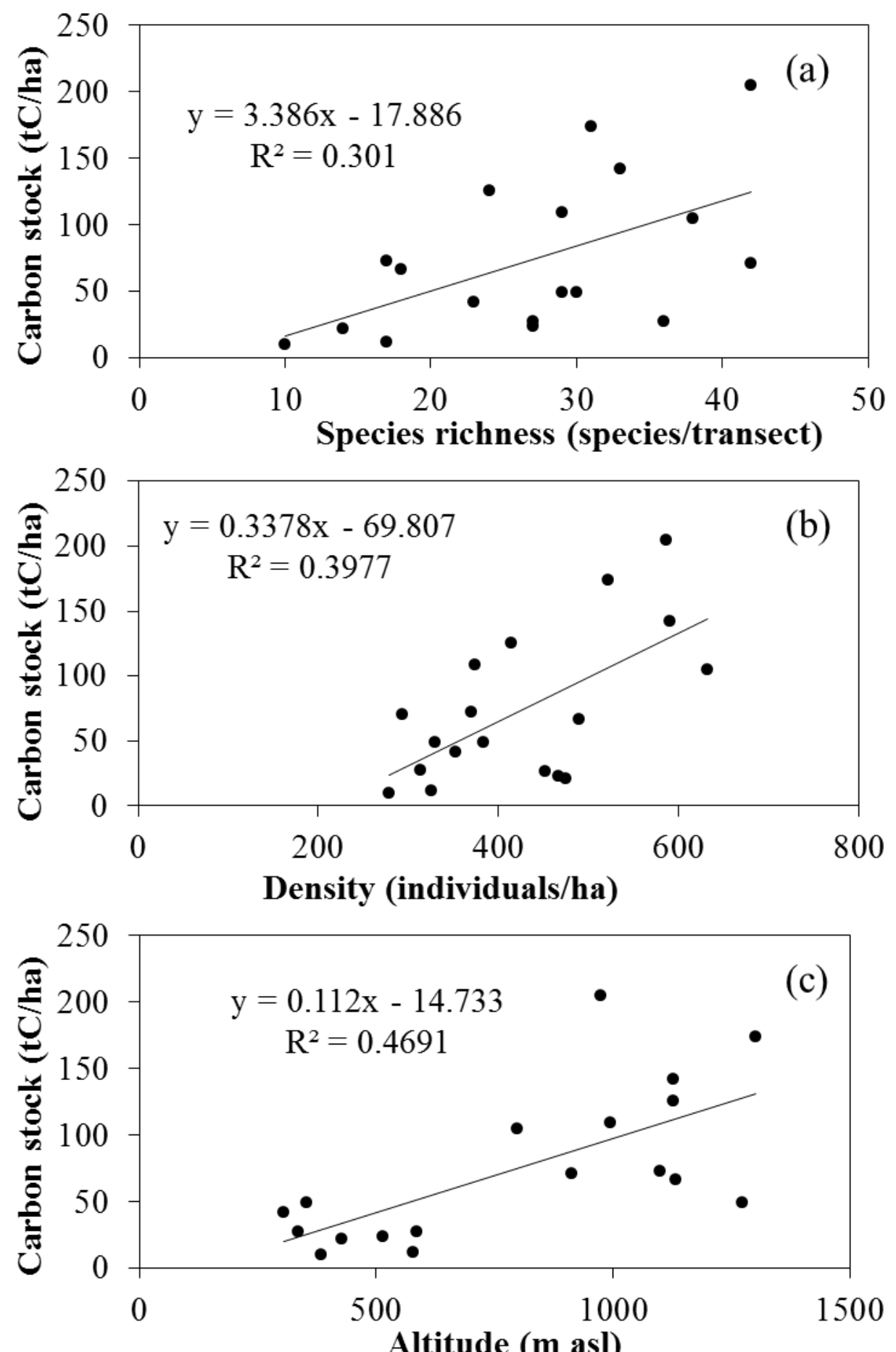

Figure 4. Relationship of carbon stock with species richness, density and altitude of transect

Several studies have been carried out to understand the role of forest ecosystem as carbon sink in different parts of the world. The carbon stock (tC/ha) recorded in $\mathrm{KH}$ $(73.7 \mathrm{tC} / \mathrm{ha})$ is greater than the carbon value reported for tropical forests at Bodamalai hills (10.94 tC/ha, Pragasan, 2015a), mixed species plantation forest $(22.25 \mathrm{tC} / \mathrm{ha})$ and Eucalyptus plantation forest (27.72 tC/ha, Pragasan \& Karthick, 2013), Kalrayan hills 
(38.88 tC/ha, Pragasan, 2015b), Shervarayan hills (56.55 tC/ha, Pragasan, 2015c), Chitteri hills (58.55 tC/ha, Pragasan, 2014) in India, Nemarket Park in Auckland, New Zealand (45.9 tC/ha, Schwendenmann \& Mitchell, 2014) lesser than Lower Montane forests at El Verde, Puerto Rico (134.21tC/ha, Jordan, 1981), tropical seasonal rain forest at Xishuangbanna, China (138.73 tC/ha, Shanmughavel et al., 2001), tropical rain forests at Khade, Ghana (152.84 tC/ha, Greenland \& Gowel, 1970), New Guinea (164.45 tC/ha, Enright, 1979), Khado Chang, Thailand (167.10 tC/ha, Kira et al., 1974), Western Ghats, India (263.47 tC/ha, Rai, 1984), Montane rain forests at New Guinea (290.38 tC/ha, Edwards \& Grubb, 1977); greater than the range reported for Pine forest at Himachal Pradesh, India (27.65-48.04 tC/ha, Shah et al., 2014); within the range reported for tropical evergreen forests at Myanmar (5.75-115.00 tC/ha, FAO, 1984-85), tropical moist forests at Bangladesh (48.88-118.45 tC/ha, Drigo et al., 1998); and lesser than the range reported for tropical moist forest at Bangladesh (86.25-120.75 tC/ha, Milde et al., 1985), Hardwood forest at Great Lakes, Northern America (96-224 tC/ha, Powers et al., 2011), tropical moist evergreen forests at Sri Lanka (109.25-299.00 tC/ha, FAO/UNDP, 1969), Red pine forest at Great Lakes, Northern America (130-195 tC/ha, Powers et al., 2011), Montane rain forests at Jamaica (131.68-179.40 tC/ha, Turner et al., 1999), tropical rain forest at Malaysia (132.25-166.75 tC/ha, Whitmore, 1975), tropical rain forests at Cambodia (200.10-238.63 tC/ha, Hozumi et al., 1979), subtropical Pine forest of Garhwal Himalayas, 203.02-230.84 tC/ha, Sheikh et al., 2012).

The order of carbon stock ( $\mathrm{tC} / \mathrm{ha}$ ) by the three forest types recognized in the Kolli hills can be justified as scrub < mixed-deciduous < semi-evergreen forest, and a similar order was observed in Chitteri reserve forest (Pragasan, 2014) and Shervarayan hills (Pragasan, 2015c) located in India. The variation in carbon storage among the three forests types can be influenced by different factors such as leaf traits, microclimate, edaphic characters, etc. Scientists have proved that forest types can alter soil organic carbon stock through several factors, including litter inputs through litterfall, root turnover, litter quality, soil chemistry (Wang et al., 2010). These above factors can indirectly affect vegetation carbon stock that varies in magnitude with varying forest types.

In the present study, carbon stock was contributed maximum (14\%) by Alseodaphne semicarpifolia Nees var. semecarpifolia. While, Memecylon edule Roxb. (8\%) contributed predominantly to the total carbon stock estimated for the Chitteri reserve forest (Pragasan, 2014), and it was Syzygium cumini L. (9\%) for the Shervarayan hills (Pragasan, 2015c). The carbon stock sequestered by a single tree was recorded maximum for Sterculia foetida L. (1.89 tC/tree) in the Kolli hill forest. While, Mangifera indica $\mathrm{L}$. had the highest carbon value $1.73 \mathrm{tC} /$ tree among tree species found in Chitteri reserve forest (Pragasan, 2014), and Artocarpus heterophyllus Lam. (2.76 tC/tree) in the Shervarayan hills (Pragasan, 2015c).

A few studies have been reported on relationship of carbon stock with species richness. In the present study, carbon stock had no significant relationship $\left(r^{2}=0.301\right)$ with species richness (Fig. 4), and similar trend was reported earlier from tropical forests (Pragasan, 2014; 2015c) as well as ago-ecosystems (Nakakaawa et al., 2009). While, some authors argue that conserving species richness increases carbon storage in forest system (Alavalapati, 2002; Kirby \& Potvin, 2007). The difference of opinion in the above case may be influenced by the nature of production system and restoration principles adopted in those forest ecosystems.

It is well known that the carbon stock of a tree is directly proportional to its stem size, and hence, total carbon stored in a forest is mostly influenced by the number of 
trees in larger stem size category rather than total tree density. In the present study, no significant relationship $\left(r^{2}=0.398\right)$ was observed between carbon stock and density (Fig. 4), and a similar trend was reported for Shervarayan hills (Pragasan, 2015c), while, a strong positive relation was observed between carbon stock and density $\left(r^{2}=0.689\right)$ at Chitteri reserve forest (Pragasan, 2014).

In the present study, carbon stock was greater at high altitude range $(104.8 \pm 20.1 \mathrm{tC} / \mathrm{ha}$, Fig. 4) when compared to low and medium altitude ranges, however, no significant variation was observed in carbon stock $(\mathrm{tC} / \mathrm{ha}$ ) values among the three altitudinal ranges (ANOVA: $\left.F_{(2,15)}=2.871, p>0.05\right)$. While, Sheikh et al. (2012), reported high carbon stock (tC/ha) at comparatively low elevation (1300 m asl, $230.84 \mathrm{tC} / \mathrm{ha}$ ) than the medium (1400 $\mathrm{m}$ asl, $218.04 \mathrm{tC} / \mathrm{ha}$ ) and high elevation $(1500 \mathrm{~m}$ asl, $203.02 \mathrm{tC} / \mathrm{ha})$. At $\mathrm{KH}$, regression analysis revealed that carbon stock had no significant relationship with altitude of forest location, a similar trend was observed earlier (Pragasan, 2014), while a positive relation $\left(r^{2}=0.570\right)$ was reported at Shervarayan hills (Pragasan, 2015c). According to Shah et al. (2014), the tree felling in higher altitude forests have failed to regenerate and lead to serious disturbances in the ecosystem functioning, particularly in forest moisture retention and local ecology, and this phenomenon emphasize strengthening protection for forest at high altitude range in $\mathrm{KH}$, for maintaining the sustainability of carbon storage in vegetation particularly at high altitudes.

The results of the present study conclude that 1) Carbon stock of $\mathrm{KH}$ is $73.7 \mathrm{tC} / \mathrm{ha}, 2$ ) Among the three forest types in $\mathrm{KH}$, carbon stock is recorded maximum for semievergreen forest $(103.5 \pm 16.6 \mathrm{tC} / \mathrm{ha}), 3)$ Among the three altitude ranges categorized in $\mathrm{KH}$, carbon stock is found maximum for high altitude range $(104.8 \pm 20.1 \mathrm{tC} / \mathrm{ha}), 4)$ Among the eleven stem size classes recognized in $\mathrm{KH}, 120-150 \mathrm{~cm}$ class has recorded maximum carbon value $(5.9 \pm 1.2 \mathrm{tC} / \mathrm{ha}), 5)$ Out of the 157 species recorded in $\mathrm{KH}$, total carbon stock is found maximum $(92.34 \mathrm{tC} / 9 \mathrm{ha})$ for Alseodaphne semicarpifolia var. semecarpifolia, 6) Among the 49 families recorded in $\mathrm{KH}$, total carbon stock is found maximum (126.10 tC/9ha) for Lauraceae, 7) Regression analysis reveals that there is no significant relationship of carbon stock (tC/ha) with tree species richness, density and altitude of forest location. The study provides valuable data on carbon stock of tree vegetation of $\mathrm{KH}$ forest useful for better management and monitoring of tree carbon stock in study site. Creating awareness on forest carbon sinks to the local inhabitants is at most the prime need for forest protection from illegal timber extraction that causes irreversible reduction in carbon stock, which negatively affects atmospheric carbon capture process for mitigation of global warming and climate change.

Acknowledgements. I sincerely thank Dr.N.Parthasarathy, Professor of Ecology and Environmental Sciences, Pondicherry University, Puducherry, for all his support and encouragements.

\section{REFERENCES}

[1] Alamgir, M., Al-Amin, M. (2008): Allometric models to estimate biomass organic carbon stock in forest vegetation. - Journal of Forest Research 19:101-106.

[2] Alavalapati, J.R.R., Stainback, G.A., Carte, D.R. (2002): Restoration of the longleaf pine ecosystem on private lands in the US South: an ecological economic analysis. Ecological Economic 40: 411-419. 
[3] Atjay, G.L., Ketner, P., Duvignead, P. (1979): Terrestrial primary production and phytomass. - In: Bolin, B., Degens, E.T., Kempe, S. (eds) The global carbon cycle. Wiley and Sons, New York, USA, pp 129-182

[4] Bhat, D.M., Ravindranath, N.H. (2011): Above-ground standing biomass and carbon stock dynamics under a varied degree of anthropogenic pressure in tropical rain forests of Uttara Kannada district, Western Ghats, India. - Taiwania 56(2):85-96

[5] Brown, S., Lugo, A.E. (1982): The storage and production of organic matter in tropical forests and their role in the global carbon cycle. - Biotropica 14:161-187

[6] Brown, S., Gillespie, A.J.R., Lugo, A.E. (1989): Biomass estimation methods for tropical forests with applications to forest inventory data. - Forest Science 35:881-902

[7] Cao, T., Valsta, L., Makela, A. (2010): A comparison of carbon assessment methods for optimizing timber production and carbon sequestration in Scots pine stands. - Forest Ecology and Management 260:1726-1734.

[8] Dixon, R.K., Brown, S., Solomon, R.A., Trexler, M.C., Wisniewski, J. (1994): Carbon pools and flux of global forest ecosystems. - Science 263:185-190

[9] Drigo, R., Shaheduzzaman, Md, Chowdhury, J.A. (1998): Inventory of forest resources of south Sylhet forest division. Assistance to the forestry section - phase ii. FAO/UNDP project BGD/85/085, field document no.3, Rome, Italy

[10] Edwards, P.J., Grubb, P.J. (1985): Studies of mineral cycling in a Montane Rain forest in New Guinea, I-Distribution of organic matter in the vegetation and soil. - Journal of Ecology 65:1943-1969

[11] Enright, N.J. (1979): Litter production and nutrient partitioning in rain forests near Bulolo, Papua New Guinea. - Malaysian Forester 42:202-220

[12] FAO (1984-85) Forest department of Burma. National forest survey and inventory of Burma. FO:BUR/79/001, working papers nos.5,7-12, Forest department of Burma, Rangoon

[13] FAO/UNDP (1969) Pre-investment study on forest industries development. Ceylon, Final Report, vol. II. Forest resources and management. FAO/SF:60/CEY-5, Rome, Italy

[14] Greenland, G.J., Gowel, J.M.L. (1970): Nutrient content of the moist tropical forests of Guana. - Plant Science 12:154-174

[15] Houghton, J.T. (1996): Climate change. The science of climate change. - Cambridge University Press, Cambridge, UK

[16] Hozumi, K., Yoda, K., Kira, T. (1979): Production ecology of tropical rain forests in south western Cambodia. II. Photosynthetic function in an evergreen seasonal forest. Nature and Life in Southeast Asia 6:57-81

[17] IPCC (2007) Climate Change 2007 - Impacts, Adaptation and Vulnerability. Contribution of Working Group II to the Fourth Assessment Report of the IPCC. IPCC, Geneva

[18] Jackson, M., Ford-Lloyd, B., Parry, M. (2014): Plant genetic resources and climate change. CAB International.

[19] Jordan, C.F. (1981): Productivity of tropical forest and its relation to a energy storage. Journal of Ecology 59:127-142

[20] Kira, T., Ogawa, H., Yoda, K., Ogina, K. (1974): Primary production by a tropical rain forest of southern Thailand. - Botanical Magazine 77:425-429

[21] Kirby, K.R., Potvin, C. (2007): Variation in carbon storage among tree species: implications for the management of a small-scale carbon sin project. - Forest Ecology and Management 246:208-221

[22] Levy, P.E., Cannell, M.G.R., Friend, A.D. (2004): Modelling the impact of future changes in climate, carbon dioxide concentration and land use on natural ecosystems and the terrestrial carbon sink. - Global Environmental Change 14(1):21-30

[23] MacDicken, K.G. (1997): A guide to monitoring carbon storage in forestry and agro forestry projects USA. Winrock International Institute for Agricultural development, USA

[24] de Milde, R., Shaheduzzaman, Md., Drigo, R. (1985): The high forest in Chittagong district. Vols 1 and 2, FAO/UNDP Project BGD/79/017, field document no.3, Rome, Italy 
[25] Miria, A., Khan, A.B. (2015): Growth and carbon storage study in some multipurpose tree species of Pondicherry area. - Indian Forester 141(6):625-629

[26] Mohanraj, R., Saravanan, J., Dhanakumar, S. (2011): Carbon stock in Kolli forests, Eastern Ghats (India) with emphasis on aboveground biomass, litter, woody debris and soils. - iForest 4:61-65

[27] Muraoka, H., Saitoh, T.M., Nagai, S. (2015): Long-term and interdisciplinary research on forest ecosystem functions: challenges at Takayama site since 1993. - Ecological Restoration 30:197-200

[28] Nakakaawa, C., Aune, J., Vedeld, P. (2009): Changes in carbon stocks and tree diversity in ago-ecosystems in south western Uganda: what role for carbon sequestration payments? New Forests, doi 10.1007/s11056-009-9180-5

[29] NOAA (2015) http://www.esrl.noaa.gov/gmd/ccgg/trends/. National oceanic and atmospheric administration, US.

[30] Pearson, T.R.H., Brown, S., Sohngen, B., Henman, J., Ohrel, S. (2014): Transaction costs for carbon sequestration projects in the tropical forest sector. - Mitigation Adaptation Strategy Global Change 19:1209-1222

[31] Powers, M., Kolka, R, Palik, B., McDonald, R., Jurgensen, M. (2011): Long-term management impacts on carbon storage in Lake States forests. - Forest Ecology and Management 262:424-431

[32] Pragasan, L.A. (2014): Carbon stock assessment in the vegetation of the Chitteri Reserve Forest of the Eastern Ghats in India based on non-destructive method using tree inventory data. - Journal of Earth Science \& Climatic Change 6:314

[33] Pragasan, L.A. (2015a): Total carbon stock assessment from the tropical forests of Bodamalai hills located in India. - Journal of Earth Science \& Climatic Change 6:273

[34] Pragasan, L.A. (2015b): Assessment of tree carbon stock in the Kalrayan hills of the Eastern Ghats, India. - Walailak Journal of Science \& Technology 12:659-670

[35] Pragasan, L.A. (2015c): Total carbon stock of tree vegetation and its relationship with altitidunal gradient from the Shervarayan hills located in India. - Journal of Earth Science \& Climatic Change 6:273

[36] Pragasan, L.A., Karthick, A. (2013): Carbon stock sequestration by tree plantations in university campus at Coimbatore, India. - International Journal of Environmental Sciences 3:1700-1710

[37] Pragasan, L.A., Parthasarathy, N. (2010): Landscape-level tree diversity assessment in tropical forests of southern Eastern Ghats, India. - Flora 205:728-737

[38] Rai, S.N. (1984): Above ground biomass in tropical rain forests of Western Ghats, India. - Indian Forester 8:754-764

[39] Schwendenmann, L., Mitchell, N.D. (2014): Carbon accumulation by native trees and soils in an urban park, Auckland. - New Zealand Journal of Ecology 38:2

[40] Shah, S., Sharma, D.P., Pala, N.A., Tripathi, P., Kumar, M. (2014): Temporal variations in carbon stock of Pinus roxburghii Sargent forests of Himachal Pradesh, India. - Journal of Mountain Science 11(4):959-966

[41] Shanmughavel, P., Zheng, Z., Liqiing, S., Min, C. (2001): Floristic structure and biomass distribution of a tropical seasonal rain forest in Xishuangbanna, southwest China. Biomass and Bioenergy 21:165-175

[42] Sheikh, M.A., Kumar, S., Kumar, M. (2012): Above and below ground organic carbon stocks in a sub-tropical Pinus roxburghii Sargent forest of the Garhwal Himalayas. Forest Studies in China 14(3):205-209

[43] Sicard, P., Dalstein-Richier, L. (2015): Health and vitality assessment of two common pine species in the context of climate change in Southern Europe. - Environmental Research 137:235-245

[44] Takimoto, A., Nair, P.K.R., Nair, V.D. (2008): Carbon stock and sequestration potential of traditional and improved agroforestry systems in the West African Sahel. Agriculture, Ecosystems and Environment 125:159-166 
[45] Teobaldelli, M., Somogyi, Z., Migliavacca, M., Usoltev, V.A. (2009): Generalized functions of biomass expansion factors for conifers and broadleaved by stand age, growing stock and site index. - Forest Ecology and Management 257:1004-1013

[46] Turner, J., Gessel, S.P., Lambert, M.J. (1999): Sustainable management of native and exotic plantations in Australia. - New Forests 18:17-32

[47] Wang, H., Liu, S., Mo, J., Wang, J., Makeschin, F., Wolff, M. (2010): Soil organic carbon stock and chemical composition in four plantations of indigenous tree species in subtropical China. - Ecological Restoration 25:1071-1079

[48] Whitmore, T.C. (1975): Tropical rain forests of the Far East. - Clarendon Press, Oxford, and Oxford University Press, London

[49] WHO- http://www.who.int/globalchange/climate/summary/en/index5.html)

[50] Timilsina, N., Escobedo, F. J., Staudhammer, C. L., Brandeis, T. (2014): Analyzing the causal factors of carbon stores in a subtropical urban forest. - Ecological Complexity $20: 23-32$ 